\title{
The Role of Politics in Governance and Service Delivery: Focus on Water Provision in Akure, Nigeria
}

\author{
LAWAL, Olubunmi Lukman ${ }^{1,}$ and OLORUNFEMI, Samuel Oluwaseyi ${ }^{2}$ \\ ${ }^{1}$ Centre for Continuing Education, Federal University of Technology Akure, Nigeria \\ ${ }^{2}$ Department of Transport Management Technology, Federal University of Technology Akure, Nigeria
}

\begin{abstract}
This study examines the role of politics in governance and service delivery (with a particular interest in water provision) in Akure, Nigeria. To achieve the above, the following objectives were made: examine the part of politics in water delivery in Akure by evaluating the roles of past and present administrations (1999-2017) in water delivery, identify various factors inhibiting and enhancing water delivery in the area. To fully capture these objectives, four residential neighborhoods (Ijapo Housing Estate, Shagari Village, Oke-Ogba and Alaba-Layout Apatapiti) were purposively selected for questionnaires administration. The numbers of residential buildings in the four selected locations were determined to represent the research population. In all, there are two thousand eight hundred and eight one (2881) residential buildings in the neighborhoods. Using systematic sampling method of selecting one head of household at every 10th building intervals across the locations, two hundred and eighty-eight (288) copies of questionnaire were administered, collated and analyzed. Also, the General Manager of Ondo State Water Corporation saddled with the responsibility of providing water to the teeming inhabitants of Akure was investigated. Data obtained from both sources were collated and analyzed and presented using the descriptive statistical method. The results revealed the policies, programmes, pitfalls, and achievements of successive governments of Ondo State in Water provision from 1999-2017. Based on these findings, practicable and insightful recommendations were made.
\end{abstract}

Keywords: Governance, Government, Politics, Service Delivery, Akure

\section{Introduction}

The efficient and effective service delivery for the people is key factors to the existence of any government (Bolatito and Ibrahim, 2014). The provisions of essential services are vital to poverty alleviation and the key to realizing the Millennium Development Goals (MDGs) both directly and indirectly (Hernandez, 2006). Service delivery is commonly used to describe public goods, basic services, amenities and infrastructures provided by the government such as hospital, road, electricity, water supply, sanitary services, physical infrastructure, town planning, housing among others (Gafar, 2017). They are tangible and intangible goods provided by the government in order to improve the well-being of the citizenry (Kayode. al, 2013). The desire to promote excellence and improve citizen satisfaction led to the launch of the Nigerian Service Delivery Initiative in 2004 (Igbuzor, 2017).

The cardinal place of service delivery in an economy was equally underscored in the United States of America by the Infrastructure Improvement Act of (2006). The Improvement Act sees infrastructure or service as normality and facilities such as water supply and distribution system, waste water collection and treatment facilities, surface transportation facilities, mass-transit facilities, airports and airway facilities, resources recovery facilities, 
waterways, levees and related flood-control facilities, docks or ports, school buildings and solid waste disposal facilities (Uhunmwuangho and Ekpu, 2012). Adequate provisions of these services will not only promote socioeconomic wellbeing of the citizens but will also engender the overall development of a country. The public service of any country is saddled with the responsibility of delivering, distributing and maintaining social services (Igbuzor, 2017). They formulate and implement the decisions and policies of the government (Oyedele, 2015).

The successes of any government in carrying out its statutory and constitutional responsibilities depend to a large extent on the type of civil service which a country has(Bamigbetan, 2016).In an ideal democratic system, the justification for the existence of any government is based on its ability to meet the basic needs of its citizens in a more prompt, effective and affordable way. Doing so would automatically boost the chances of democratic sustainability (Gafar, 2017). For a particular government or opposing party to remain relevant in society, lots of strategic and innovative politics or politickings come to play. In the context of this research, politics is defined as the general process of carrying out the business of government (Ichima, 2014). It deals extensively with the consequences and outcomes of human actions in the quest and struggles for survival, prominence, and relevance (Omotoso, 2014).

Marx Weber defines politics as the struggle for power. Lasswell (1930) defines it as the game of who gets what, when and how of the public resources. Easton (1957) on the other hand sees politics as the authoritative allocation of values for the general benefit of all (Ichima, 2014). It is an instrument deployed to gain power for the sole aim of providing essential services for the citizens. Politics captures the essence of peoples' wants, needs, sufferings, aspirations, expectations within a given human community. In an ideal society, the contestation for power should be for the overall benefit of the people as succinctly captured by David Easton. One way of measuring the success and or failure of governments in modern societies is to assess how successful such governments are in developing conditions necessary for satisfying the basic needs of the people they govern (Ayo, 2000:19). For example, Arowolo and Aluko (2012) posit that most people in Nigeria desire economic development and the physical improvement of their infrastructure and environments.

The hallmark of politics is governance and the hallmark of governance is service delivery. When politics is evolved to meet the needs of the citizens timely and sustainably across space without discrimination and when the citizens are involved or carried along in the decision-making process, participatory governance is said to be entrenched (Natufe, 2006). Governance refers to how the politics of a nation is carried out (Okpaga, 2009). World Bank (2003) sees governance as the exercise of authority in the name of the people. In an ideal society, governance should guarantee civil and human rights, efficiency and accountability (Johnson, 1991). Judging from the above, Arowolo and Aluko (2012) posits that government and its institutions must, as a matter of welfare policy, be propoor and should promote human development of all citizens. Since the return to civil rule in the year 1999, the successive government in Nigeria (federal, state and local)rode to power on the premises that they will provide the basic services necessary for healthy and sustainable living for the citizens. Despite several class struggles for power and gaining of power, plans and a massive injection of international and domestic resources to improve service delivery system, public service delivery is still failing in Nigeria and many other developing countries (Leni et. al, 2012).

In view of the above, this study, therefore, attempts to assess the role of politics in governance and service delivery (focus on water provision)in Akure, Nigeria with a view of suggesting innovative strategies for effective governance and service delivery. The prevailing issues of interest are to examine the part of politics in governance and service delivery in Akure with a particular interest in water provision. This will be done by evaluating the roles of past and present administrations (1999-2017) in water delivery, identify various factors inhibiting and enhancing water delivery in Akure, Ondo State. Several basic services, infrastructures or amenities exist but the water was carefully selected because it is one of the basic and incontrovertible requirements of life recognized across the globe.

\section{Relevant Literatures}

\subsection{Governments as an Instrument of Service Delivery in Nigeria}

Nigeria operates a federal system of government. The three tiers of government (federal, state and local) are constitutionally empowered to provide basic services (public utilities, security, economic development projects and enforcement of the law) for the citizens. Adequate autonomy is given to each level of government to enable it to perform its responsibility without frustration (Majekodunmi, 2015). The nation's economic resource is controlled by the Federal government which makes monthly allocations to both state and local governments with a stipulated sharing formula (Nweke, 2015). The bulk of service provision or infrastructure financing in Nigeria comes from 
direct budget investment from fiscal resources, borrowing, and market-based financing. A large number of urban infrastructures in Nigeria were financed through direct budget expenditures from the three tiers of government (Central, State, and local governments) under the supervision of both elective and political appointees (Ogunlanaet. $a l, 2016)$.

Therefore, contestation for power, gaining of power and aftermath political development process could be seen as a state of economic and political transformation and how it impacts positively on the standard of living of the citizens, with regards to income, housing, health, education and other related needs (Ekpung and Onenu, 2013). Kabuya (2011) posits that government exists to execute developmental projects and services that will improve people's lives. In view of the above, present and future development of a nation is hinge on the capability of its government and her agencies to provide and reinvent scientifically and philosophically of management that is capable of rendering socio-economic needs to the citizens (Bonnie and Kehinde, 2007). Hoogwout (2010) posits that citizens are demanding increased convenience in their interaction with the government.

The interaction between citizens and the government is through service delivery. As such, improving service delivery to individual citizens raises not only trust in the government but it also confers legitimacy on the government (Hoogwout, 2010). As aptly captured by Gafar (2017), the existence of any government is presumed on its ability to fulfill the basic necessity of the lives of its citizens. Simply put, the existence of government is justifiable on the basis that supplies crucial services such as security of lives and properties, maintaining orderliness, providing social amenities and infrastructure, and offer a legal framework for conflicts prevention and resolution and acceptable system of justice. Suffice it to say that for the government to gain the support of the citizen, it should strive to fulfill its own part of a social contract agreement with its citizen.

\subsection{Politics, Governance and Service Delivery: the interface}

A lot of political intrigues come to play in governance and service delivery. Obama (2009) and Rodrik (2008) cited in Kabuya (2011) opines that good governance is an instrument for achieving better policymaking and improved economic outcomes. Politics anchored on the principles of good governance will bring about effective service delivery. Akuju and Enyioko (2014) defined effective service delivery as services characterized by timeliness, adequacy, satisfaction (of the citizens), fairness, honesty, and transparency. As observed by Ichima (2014), the locations of development projects are determined by politics. The politicians who are able to influence the party in power end up bringing development projects to their constituencies.

Where there are no strong and influential politicians, therefore, the constituencies are neglected and starved of development projects. This implies that development projects are therefore not necessarily located on the basis of need and that accounts for why some areas are crowded with government projects at the expense of other areas in Nigeria. For Nigeria to attain its desired level of development and better the lives of its teeming population service delivery system must be a rethink and redirected towards fairness, equitability, rule of law, responsiveness, accountability, wealth redistribution, and profit maximization must be regulated and justifiable.

\subsection{Water}

Access to safe drinking water is an indispensable human right as much as clean air, but, the majority of the world's population lacks access to it (Lawal and Basorun, 2015). Despite several billions of dollars in export revenues since the discovery of oil in the late 1950s, at least half of Nigerians still live in abject poverty without access to clean water (Ojo, 2012). This lack of access to clean water and sanitation infrastructure has been linked with poor health outcomes and, by extension, loss of productivity (Pouliquen 2000, Brenneman and Kerf 2002; Zhang 2012). Sustainable infrastructure in water and sanitation can help connect nearly a billion people who currently lack access to water supply around the world (World Bank, 2010).

\subsection{Constraints to Governance and Service Delivery}

Igbuzo (2017) and several authors highlight constraints to effective governance and service delivery in Nigeria to include:

i. Cost of governance: The cost of governance in Nigeria is disproportionately high relative to productivity (Okeke and Eme, 2015). There is a long list of ministers, commissioners, special advisers, special assistants, a retinue of aides and several other political appointments with high remuneration (Famutimi, 2012). Costs associated with the running of the government have increased dramatically over the years such that an increasingly reduced proportion 
of public revenue is available to support and implement the primary functions of government (CBN, 2005). Consequently, the major purposes of government have been hindered (Ejuvbekpokpo, 2012). Cost of governance in Nigeria is not a direct effect of positive policies of government for the enhancement of the living standard of the people, but basically as a result of inflated contracts and other vices by government officials for their personal enrichment.

ii. Effective Budgeting and Public Finance Management: A budget is simply the statement of expected income and expenditure over a time period, usually a year of the government. It is a comprehensive document that outlines what economic and non-economic activities a government wants to undertake with special focus on policies, objectives, and strategies for accomplishments that are substantiated with revenue and expenditure projections (Ugoh and Ukpere, 2009). The major advantage of budgeting is to guarantee orderly development. Governance without effective budgeting will definitely result in haphazard development if there is development at all (Ojo, 2012). The budget has been described as the most important document for the development of any country. It is the most powerful way that a government can meet the needs and priorities of the citizens. The budget process is crucial to good development outcomes. Corruption in any country starts from the budgetary process.

In very corrupt countries, the budget is done in secret. Releases are done without the knowledge of citizens. Procurement information is not made available to citizens and corruption is guarded and protected. Effective budgeting requires an open budget system. A budget is regarded as open if citizens have access to the key budget documents; have a high level of involvement in the budgetary process and have access to procurement information. The Open Budget Index 2012 scores Nigeria 16 out of 100 which is a poor rating of the quality of budgeting in Nigeria. More often than not, the successive government in Nigeria failed to implements budget proposal $100 \%$ at the end of every financial or calendar year.

Also, some sectors of the economy lack transparency and accountability. Most of their activities were shrouded in secrecy. For example, there is still a lack of transparency in the oil and gas sector. Oil theft continues unabated despite the effort of government and security agencies. According to NEITI Audit report 2009-2011, Nigeria losses N578.990 billion annually to oil theft and NNPC owes the government \$5.8 billion from Liquefied Natural Gas which has not been paid into the federation account since 2006. There are still late releases of funds to ministries, departments, and agencies. There is improper project design, costing, monitoring, and audit. The end result is low capital budget implementation and unsatisfactory public expenditure outcomes

iii. Planning: There is no systematic planning framework for the country that ensures that adequate data and research, good information system, monitoring and evaluation and tracking of results. The end result is an abandonment of projects, poor plan implementation, and poor service delivery. For instance, it has been documented by the Presidential Assessment Committee report that 11,886 projects worth N7.7 trillion have been abandoned across the country denying citizens of the benefits (Igbuzo, 2017). The concomitant effect of poor planning and budgeting are lingering poverty, stunted economic growth, and development (Ojo, 2012).

iv. Civil Service Reform: In the civil service today, there is the culture of self-interest and patronage. The recruitment process does not supply the right people in the right numbers to the right places to meet the service needs of citizens. The civil servants are not managed, promoted or rewarded based on objective measures of performance. The end result is that the civil service functions as an employment mechanism and not a service delivery mechanism with the with over 70 percent recurrent expenditure. Consequently, there is poor delivery of public goods and services.

v. Sectoral Issues: The ministries, department, and agencies (MDAs) in the different sectors such as trade, agriculture, education, health, and security are expected to deliver government services to meet the needs of Nigerians. But the poor recruitment and posting, lack of motivation, poor allocation of resources and poor management have resulted in weak capacity, weak accountability and poor performance of the MDAs.

vi. Constituency projects: Constituency projects constitute a huge challenge to organizational effectiveness in the public sector. Most of the projects are put in the budget without proper design and costing. The nature, location, and choice of contractors for the projects are determined solely by political considerations. The end result is an abandonment of projects, poor execution and poor service delivery to citizens.

vii. Corruption: Corruption is no doubt a global phenomenon that has threatened and still continues to threaten the developmental efforts in many nations (Kayode et. al, 2013).Corruption is widespread and endemic in Nigeria. It is arguably one of the greatest challenges leading to underdevelopment and poor service delivery in Nigeria. Despite the plethora of legislation and agencies fighting corruption in the country, corruption has remained widespread and pervasive because of failure to utilize universally accepted and tested strategies; disconnect between posturing of leaders and their conduct; lack of concrete sustainable anti-corruption programming and failure to locate the anticorruption struggle within a broader struggle to transform society. According to Omotoso and Abe (2014), most people are vying for political offices this day to feather their own nest. That is they are clamoring for power for 
their primordial and self-interest over and above the common good and general will of the Nigerian people. The obvious outcome has been a corrupt, undemocratic and self-seeking leadership and style of governance by this elite class that is more interested with the sharing of the country's resources than with the ideals of good or effective governance - equity, fairness, justice, and transparency. The attendant effect of corruption in the public service is the lack or inadequate provision of services that would enhance the standard of living of Nigerians. Ichima (2014) posits that corruption has become endemic and eaten into the fabrics of the nation. It is primarily an outcome of the desire by elected politicians to recover monies spent during their electioneering campaigns. All contract awards are therefore shrouded in fake papers, ten percent 'kick-back' syndrome, payments for jobs not done, etc. The deteriorating standard of living of the majority of Nigerians is an evidence of the lack of basic necessities of life i.e. food, shelter and clothing and low access to essential services like health, education, power, water, transportation (Kayode et. al, 2013).

viii. Failure of Leadership: The level of good governance in any system is a function of good leadership while good management depends on good governance (Otegbulu, 2013). Since Nigeria's political independence in 1960, the country has not had the opportunity of being governed by a willing and ready leader but those that can at best be described as "accidental leaders". These are leaders whom the mantle of leadership fell on by default not minding their capacity, experience and in most cases; they were neither prepared nor expectant of such huge responsibility (Odo, 2015). Sizeable proportions of the leaders were elected base on patronage as they lack the intellectual and mental capacity to lead and evolve policies that will enhance the socio-economic development of the nation. Chimee (2009) noted that the three major strands that account for leadership failure in Nigeria are lack of ideology; ethnicity; and corruption.

Also, several researchers and authors have equally identified various factors inhibiting effective governance and service delivery. Lawal (2014) in his assessment of service provision in selected public and private residential neighborhoods Akure, Nigeria identified paucity or inadequate financial budgetary allocations, rapid population growth, lack of maintenance culture and policy discontinuities or failure of successive government to see service provision as a continuum as major factors inhibiting effective service delivery. As observed by OECD (2010), world cities face the most acute challenge of service delivery because of the fast-growing population. The population is growing at a geometric rate while the provision of basic services is growing at an arithmetic rate. Gafar (2017) also identified corruption, poor attitude of public servants, inadequate skilled and non-service oriented personnel for policy implementation as major hindrances to effective service delivery. The world development report of 2014 closely links service delivery with accountability and concludes that service delivery failed in many developing countries as a result of the failures in accountability relationship (World Bank, 2004).

\section{Materials and Method \\ 3.1 Research Locale}

Akure is a traditional Nigeria city in the Yoruba region of the country that had existed long before the advent of British colonial rule (Afolabi, 2008). The city is located within Ondo State in the South Western part of Nigeria. Akure is a medium-sized urban center which became the provincial headquarters of Ondo province in 1939 but doubles as the capital city of Ondo State and Akure Local Government headquarters in 1976. These dual political roles of Akure have since acted as an impetus to the influx of people into the city (Olujimi \& Olamiju, 2011). In terms of location, the town is located approximately 700 kilometers South West of Abuja, the Federal Capital of Nigeria and about 350 kilometers to Lagos (the former capital of Nigeria). It lies on latitude $7^{0} 15^{1}$ North of the Equator and on longitude $5^{0} 15^{1}$ east of the Greenwich meridian. It stands on the altitude of about 370 meters above the sea level according to the Ondo State Government Agro-climatological and Ecological Monitoring Unit (EMU, 2007). It shares a geographical boundary with Owo Local Government Area in the east, Akure North and Ifedore Local Government areas in the north, Ile-Oluji/Okeigbo Local Government Area in the west and Idanre Local Government Area in the South.

\subsection{Method}

To discover and appreciate the role of politics in governance and service delivery in Akure, four residential neighborhoods were selected for questionnaires administration. The questionnaires were designed to: assess the socio-economic characteristics of the respondents, evaluate the relationship between politics and service delivery/good governance, find out the roles of past and present administrations in water provision and identify various factors inhibiting and enhancing safe water provision. The number of residential buildings in the four selected neighborhoods (Ijapo Estate, Shagari village, Apatapiti, and Oke-Ogba) was determined to represent the research population. 
Altogether, there are two thousand eight hundred and eighty-one (2881) residential buildings in the study area. Using a systematic random sampling technique, a questionnaire was administered to one head of household at every 10thbuilding interval across the study area. In all, 288 buildings or heads of household were systematically selected for resident's interview. This sample size is justifiable considering the homogeneity of population and similarity in the pattern of demand for service. Equally, data bordering on water provision, treatment, and distribution processes were obtained from the Department of Engineering, Design and Statistics Ondo State Water Corporation. Data obtained from the residents were collated and analyzed using the Statistical Package for Social Science (SPSS) Version 16.

Table 1: Neighbourhoods, Research Population, and Sample Size

\begin{tabular}{llll}
\hline S/N & Neighborhood & $\begin{array}{l}\text { Research } \\
\text { Population }\end{array}$ & $\begin{array}{l}\text { Sample } \\
\text { Size } \\
(10 \%)\end{array}$ \\
\hline 1. & Ijapo & 688 & 69 \\
2. & Shagari Village & 861 & 86 \\
3. & Oke-Ogba & 579 & 58 \\
4. & Apatapiti & 753 & 75 \\
TOTAL & & $\mathbf{2 8 8 1}$ & $\mathbf{2 8 8}$ \\
\hline
\end{tabular}

Source: Authors Field Survey, 2017

\section{Results and Discussions}

To fully examine the role of politics in governance and service delivery in Akure, two hundred and eightyeight copies of structured questionnaires were administered, retrieved and analyzed. Detailed presentations of findings and inferences are as follows:

\subsection{Socio-Economic Characteristics of Respondents}

From the field survey, $42.7 \%$ of the respondents are females while $57.3 \%$ are males. Considerable proportions (52.8\%) of the respondents are between 35-64 years, closely followed by $34.4 \%$ of respondents who are between 18-34 years. The majority (68.8\%) of the sampled respondents are married. In terms of household size, most of the sampled respondents (45.2\%) have between 5-8 household sizes, $40.6 \%$ have between 1-4 and $11.8 \%$ have between 9-12. Almost all the sampled respondents are literates as $36.8 \%$ have acquired secondary education, $29.2 \%$ acquired tertiary education and $25.3 \%$ attained primary education. Only $8.7 \%$ have no formal education. Pertaining to occupational inclination, $3.4 \%$ are unemployed, $4.5 \%$ are farmers, $41 \%$ are traders or business owners, $22.6 \%$ are artisans/professionals and $28.5 \%$ are civil servants. In terms of monthly income, $32.6 \%$ of the sampled respondents earned between $\$ 40,001-\$ 60,000$ and $28.8 \%$ earned between $\$ 60,001-\$ 100,000$. Over $60 \%$ of the sampled respondents have been in the neighborhoods or Akure for a period of 10 years and above.

Table 2:Socio-economic Characteristics of Respondents

\begin{tabular}{lll}
\hline Sex of respondents & Frequency & Percentage (\%) \\
\hline Female & 123 & 42.7 \\
Male & 165 & 57.3 \\
Total & $\mathbf{2 8 8}$ & $\mathbf{1 0 0}$ \\
Age of respondents & Frequency & Percentage (\%) \\
18-34yrs & 99 & 34.4 \\
35-64yrs & 152 & 52.8 \\
65yrs & 37 & 12.8 \\
Total & $\mathbf{2 8 8}$ & $\mathbf{1 0 0}$ \\
Marital status & Frequency & Percentage (\%) \\
Single & 55 & 19.1 \\
Married & 198 & 68.8 \\
Separated/divorced & 11 & 3.8 \\
Widow/widower & 24 & 8.3 \\
Total & $\mathbf{2 8 8}$ & $\mathbf{1 0 0}$ \\
House hold Size & Frequency & Percentage (\%) \\
$1-4$ & 117 & 40.6 \\
\hline
\end{tabular}




\begin{tabular}{|c|c|c|}
\hline $5-8$ & 130 & 45.2 \\
\hline $9-12$ & 34 & 11.8 \\
\hline 13 and above & 7 & 2.4 \\
\hline Total & 288 & 100 \\
\hline Educational Qualification & Frequency & Percentage (\%) \\
\hline No formal education & 25 & 8.7 \\
\hline Primary leaving certificate & 73 & 25.3 \\
\hline Secondary leaving certificate & 106 & 36.8 \\
\hline Tertiary Education & 84 & 29.2 \\
\hline Total & 288 & 100 \\
\hline Occupation & Frequency & Percentage (\%) \\
\hline Unemployed & 10 & 3.4 \\
\hline Farming & 13 & 4.5 \\
\hline Trading/business & 118 & 41 \\
\hline Artisan/professional & 65 & 22.6 \\
\hline Civil service & 82 & 28.5 \\
\hline Total & 288 & 100 \\
\hline Monthly income & Frequency & Percentage $(\%)$ \\
\hline$\$ 5,000-\cong 18,000$ & 18 & 6.3 \\
\hline$\$ 18,001-\$ 40,000$ & 48 & 16.7 \\
\hline$¥ 40,001-¥ 60,000$ & 94 & 32.6 \\
\hline$\$ 60,001-\$ 100,000$ & 83 & 28.8 \\
\hline$\$ 100,001$ and above & 45 & 15.6 \\
\hline Total & 288 & 100 \\
\hline Length of stay & Frequency & Percentage $(\%)$ \\
\hline less than 5 years & 38 & 13.2 \\
\hline $6-10$ years & 73 & 25.3 \\
\hline $11-15$ years & 118 & 41 \\
\hline 16 years and above & 59 & 20.5 \\
\hline Total & 288 & 100 \\
\hline
\end{tabular}

Source: Authors Field Survey, 2017

\subsection{Service Delivery in Akure: Focus on Safe Water Supply}

\subsubsection{Water Provider}

From the field survey, the majority (74\%) of the sampled respondents obtained water for various uses through self-effort, $19 \%$ through government intervention, 5\% through public and private partnership and $2 \%$ through community intervention. From above, one can infer that most of the sampled respondents owned and provide water use for various purposes by themselves with little or no reliance on government.

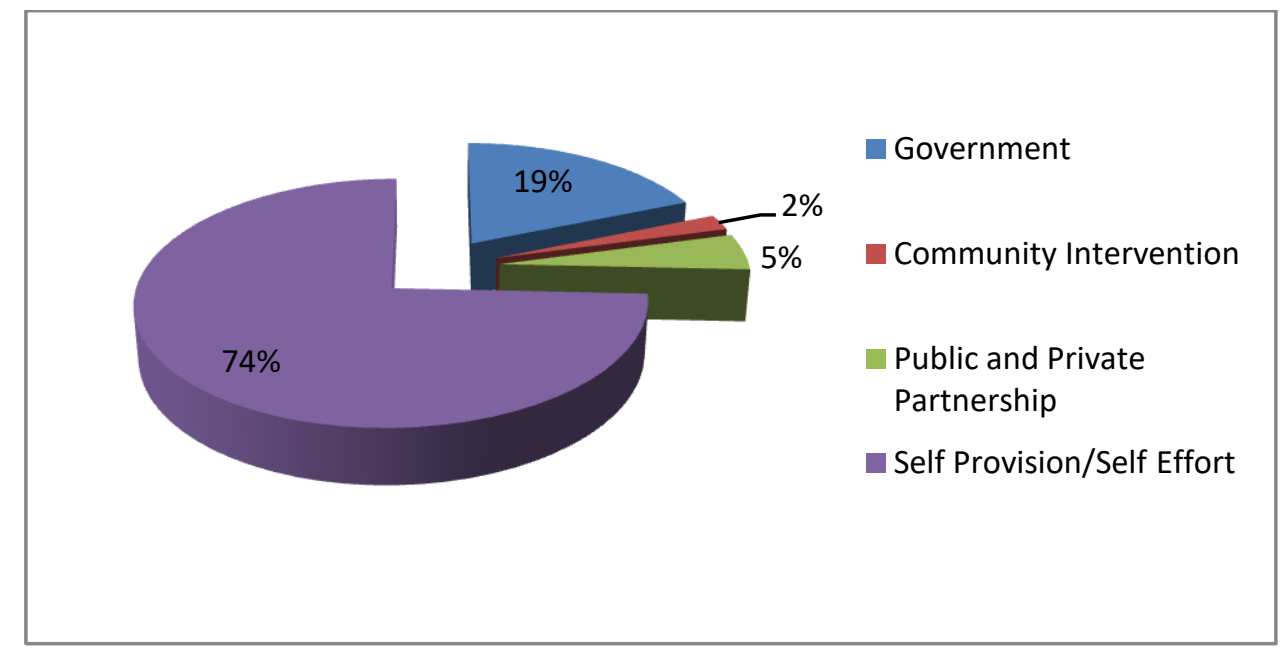

Fig. 1: Water provider 


\subsubsection{Source of Water Supply}

From the survey, well $(62 \%)$ is the major source of water supply for various uses in the selected neighborhoods, closely followed by a borehole (31\%) and pipe-borne water (6\%).

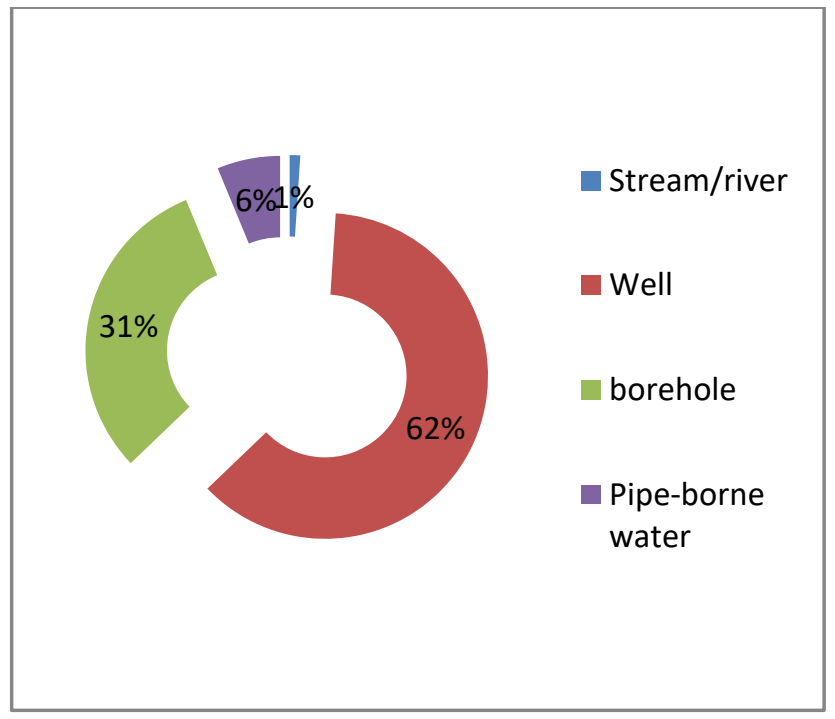

Fig. 2: Source of Water Supply

\subsubsection{Government Intervention in Water Provision}

From the survey, sizeable proportions $(45 \%)$ of the respondents declared that the government has not put in place any many measures to provide safe water in their locations, $31 \%$ said the government has constructed boreholes to complement existing sources of water supply in their locations, $13 \%$ posits that reticulations pipes have been laid underground to facilitate access to pipe-borne water and $11 \%$ said the government has developed Owena Ondo water supply scheme to boost water supply in Akure and its environs. Going by electioneering campaign to make safe water available to all by successive government and data obtained from the field survey, one can safely conclude that successive government at all levels has not put in place comprehensive measures to provide safe water to the teeming inhabitants of Akure.

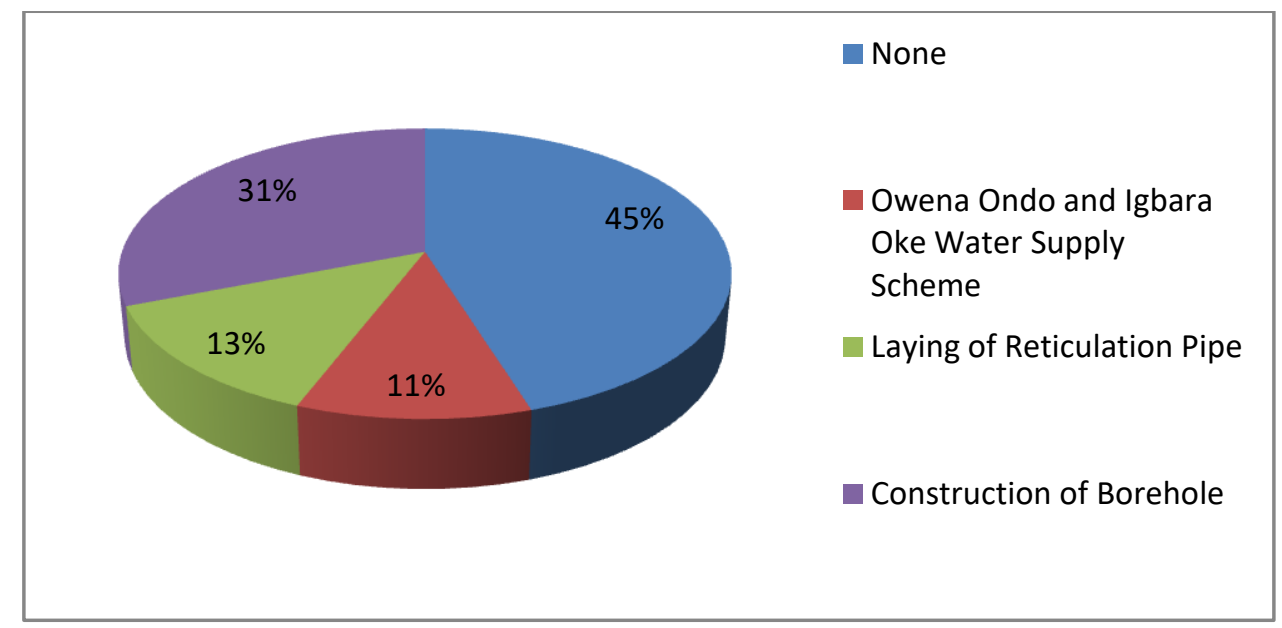

Fig. 3: Government Intervention in Water provision

\subsubsection{Quality of Water and level of Government Intervention in Water Delivery}

From the survey, $2.4 \%$ of the sampled respondents felt that they make use of poor water quality, $66.3 \%$ believed that they make use of average water quality, $24.3 \%$ believed that the quality of water was good and $7.0 \%$ said the quality of water was very good. Considering the level of government intervention in water delivery, $30.2 \%$ of 
the sampled respondents said it was very low, $49.3 \%$ said it was low, $14.2 \%$ said it was high and $6.3 \%$ said it was very high. In all, one can infer that the quality of water in the area is relatively good and the level of government intervention is abysmally low. In the same vein, one can also deduce that most of the electoral promises to provide water for all are given at face value to cajole and or hoodwink the teeming electorates to vote for those vying for elective positions.

Table 3: Quality of Water and Level of Government Intervention in Water Delivery

\begin{tabular}{llllll}
\hline $\begin{array}{l}\text { The quality of the } \\
\text { water supply }\end{array}$ & Frequency & $\begin{array}{l}\text { Percentage } \\
(\%)\end{array}$ & $\begin{array}{l}\text { Level of } \\
\text { government } \\
\text { intervention }\end{array}$ & Frequency & $\begin{array}{l}\text { Percentage } \\
(\%)\end{array}$ \\
\hline Poor & 7 & 2.4 & Very low & 87 & 30.2 \\
Average & 191 & 66.3 & Low & 142 & 49.3 \\
Good & 70 & 24.3 & High & 41 & 14.2 \\
Very good & 20 & 7.0 & Very high & 18 & 6.3 \\
Total & $\mathbf{2 8 8}$ & $\mathbf{1 0 0}$ & Total & $\mathbf{2 8 8}$ & $\mathbf{1 0 0}$ \\
\hline
\end{tabular}

Source: Authors Field Survey, 2017

\subsubsection{Part of Politics in Governance and Service Delivery (Past and Present Administrations 199-2017) and willingness to pay for safe water}

Nigeria returned to civil rule in the year 1999 after prolonged military administrations. From then till now, Ondo State has witnessed the administration of four civilian governors. Mr. Adebayo Adefarati was at the helm of affairs from (1999-2003), Dr. Olusegun Agagu (2003-2009), Dr. Olusegun Mimiko (2009-2017) and Barrister Oluwarotimi Akerodolu (2017) till date. These successive governments came on board after a vigorous electioneering campaign and elections. They all came to power on the strength of their good will, political scheming and party manifestos or campaign promises to provide basic amenities such as water, sanitation, health care, education and motorable roads amongst others to the inhabitants of Ondo State and its environs.

When the respondents were asked which of these administrations and her agency has invested more in safe water supply in Akure, 32.6\% of the sampled respondents said the administration of Adebayo Adefarati invested more in water provision, 46.9\% said Dr. Olusegun Agagu, 18.8\% said Dr. Olusegun Mimiko and 1.7\% said the incumbent governor barrister Oluwarotimi Akeredolu. From the standpoints of the respondents, investments in safe water delivery received a boost from the administration of $\mathrm{Mr}$. Adebayo Adefarati to Olusegun Agagu and started declining or receive a downward trend from the administration of Olusegun Mimiko through the administration of Barrister Oluwarotimi Akeredolu.

The above was substantiated by the General Manager of Ondo State Water Corporation through the Department of Engineering, Design, and Statistics. According to him, parts of Ondo Road, Oba Adesida road, Arakale, Hospital road, Oluwatuyi road, Oshinle quarters, Alagbaka, Ijapo, and Oba-Ile had access to pipe borne water during the reigns of Adebayo Adefarati. They were serviced through Owena Ondo Road and Owena Igbara Oke Water Supply Schemes complemented with water reservoirs sited at Nepa. When Dr. Olusegun Agagu came on board, the scope of the schemes was expanded, more revenue was allocated for water provisions and boreholes were constructed at different locations such as Shagari village, Oke-Ogba, Apatapiti, and Ijapo Estate.

All through the administrations of Adebayo Adefarati and Olusegun Agagu, water was regarded as social or public goods but when Dr. Olusegun Mimiko came on board; water was no longer regarded as public goods but seen as economic goods and government investment in the provision of water reduced drastically. During his reigns, Owena Ondo Road water supply scheme collapsed, some of the boreholes at Oke-Ogba and Shagari village stop functioning, Nepa reservoir rarely supply with water and most of these locations that had access to safe water up to when he came on board were deprived of safe water. Dr.Olusegun Mimiko was more interested in health services and road constructions and fittings in Akure. When Oba-Ile road was dualized and supply with street furniture, the underline reticulation pipes supplying water to Ijapo and Oba-Ile axis were destroyed resulting in the disconnection of these areas from the schemes. 
Since Barrister Oluwarotimi Akeredolu came on board in 2017, the investment in safe water delivery has been at the lowest ebb. Apart from boreholes that are still working in some locations, water supply operations through government and her agency are nearly down in Akure and its environs. In monetary term, Adebayo Adefarati (1999-2003) invested almost $\$ 700$ million (\$19,390,58.2)in water provision during his tenure, Dr. Olusegun Agagu (2003-2009) invested over $\$ 2$ billion (\$55,401,66.205), Dr. Olusegun Mimiko (2009-2017) invested over $\$ 300$ million $(\$ 8,310,25)$ and Barrister Oluwarotimi Akeredolu (2017 till date) has invested $\$ 1.2$ million $(\$ 3,324.1)$ in water provision. Despite campaign promises to make water available to all, one can deduce that government is no longer interested in investing a substantial amount of money in water provision. As such, the respondents were asked if they are willing to pay for the improved source of water supply, 54\% of the sampled respondents said they are willing to pay for the improved source of water supply and $46 \%$ said they are not willing to pay.

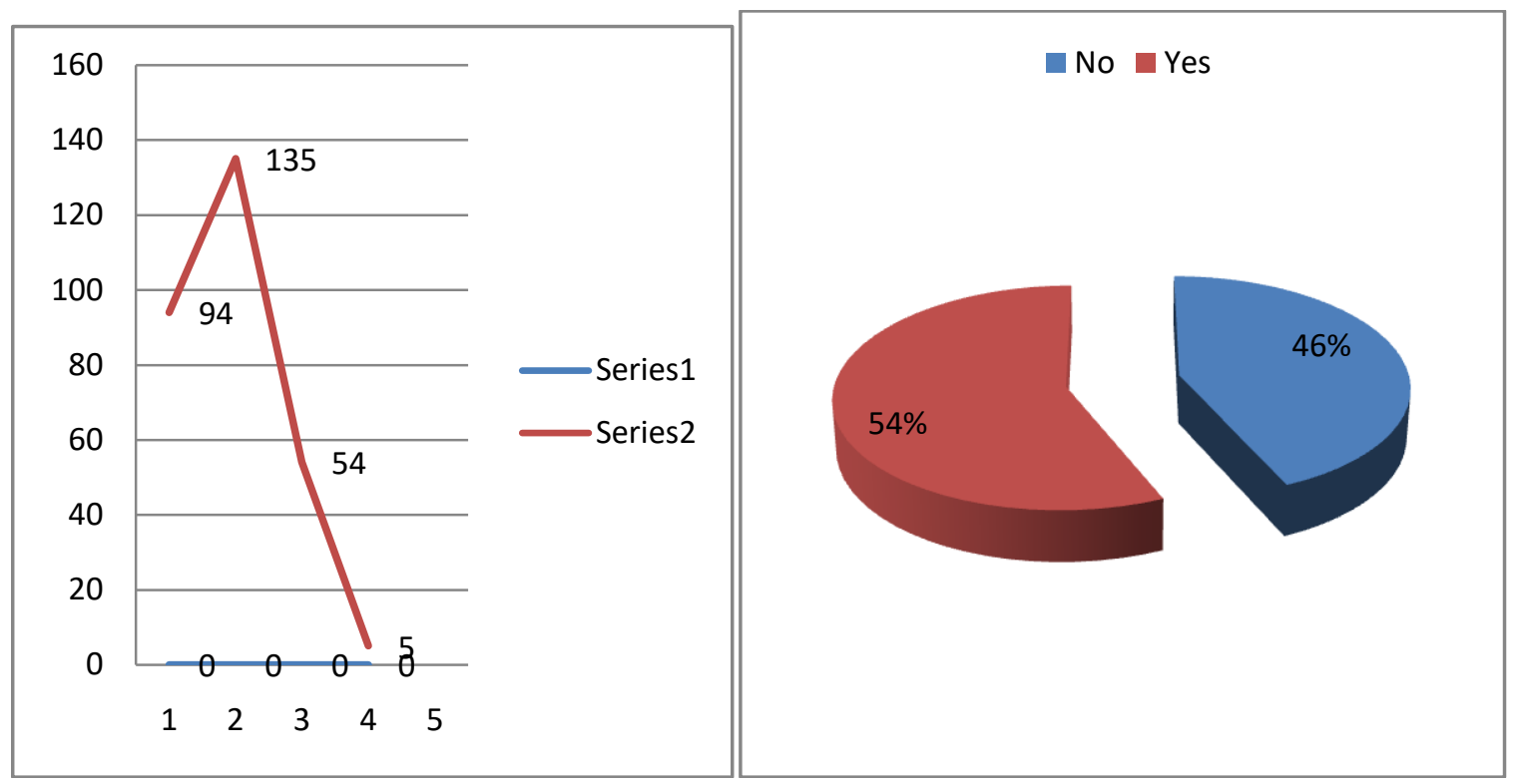

Fig. 4: Investment in safe water

Fig. 5: Willingness to pay for safe water

\subsubsection{Factors inhibiting seamless Safe Water Supply and Possible Solutions}

From the field survey, the majority $(50.3 \%)$ of the sampled survey posits that failure of government at all levels to invest sustainably on safe water has made access to safe water relatively high, 28.15 said investment in safe water is capital intensive and as such most government will not want to invest more since there will be no returns on their investment, 9.8\% said that successive governments lack maintenance culture. This explains why they have not repaired the Ondo Owena Water Scheme and several boreholes that are no longer functioning. On the part of Ondo State Water Corporation, the following factors were identified to be inhibiting seamless safe water supply: lack of maintenance culture, erratic power supply by National Electricity Power Authority (NEPA) which later metamorphosed to Power Holding Company of Nigeria (PHCN) and now unbundled and managed by ten Distribution Companies (DISCOs) and five Generation Companies (GENCOs), high cost of diesel and petroleum required to generate, treat and distribute water and apathy on the part of successive government to optimally provide financial and other resources required for full scale operations.

To fully address the above problems, $39.6 \%$ of the respondents said government should encourage public and private partnership in safe water provision, $23.3 \%$ said that successive government should allocate and invest more in portable water provision, $22.2 \%$ said that moribund or disrepair dams and boreholes should be rehabilitated an area cut off from safe water supply should be reconnected and $14.9 \%$ said residents should be willing to pay a substantial amount of money to gain access to safe water. In the same vein, Ondo State Water Corporation believed that reduction of non-revenue water standpoints, rehabilitation of Ondo Owena Water Scheme, provision of necessary funds required to make water available to the end users and encouragement or creating an enabling 
environment for private investors in water delivery through Public and Private Partnership (PPP) will enhance seamless safe water supply in Akure.

The corporation further stressed that the existing water supply schemes (Ondo Owena and Igbaraoke) require catchment management such as dredging, desilting and erosion control. There is also a need for system improvement, system engineering improvement, system operation, and maintenance and the provision of critical input like chemicals and power/electricity either through Benin Electricity Distribution Company or power generating plants. In the estimate of the Water Corporation, a sum of almost $\$ 2$ billion $(\$ 55,401,66.205)$ will be required to put all these measures in place.

Table 4: Factors inhibiting seamless Safe Water Supply and Possible Solutions

\begin{tabular}{|c|c|c|}
\hline Major factor militating against safe water supply & Frequency & Percentage $(\%)$ \\
\hline $\begin{array}{l}\text { Misappropriation of funds allocated for safer } \\
\text { water provision }\end{array}$ & 9 & 3.1 \\
\hline Lack of maintenance culture & 28 & 9.8 \\
\hline Safe water provision is capital intensive & 81 & 28.1 \\
\hline $\begin{array}{l}\text { Failure of government to invest sustainably on } \\
\text { safe water scheme }\end{array}$ & 145 & 50.3 \\
\hline Rocky terrain or landscape & 25 & 8.7 \\
\hline Total & 288 & 100 \\
\hline Means of improving safe water supply & Frequency & Percentage $(\%)$ \\
\hline $\begin{array}{l}\text { Average citizens should see water as economic } \\
\text { goods and should pay to have access to safe } \\
\text { water }\end{array}$ & 43 & 14.9 \\
\hline $\begin{array}{l}\text { The successive government should allocate and } \\
\text { invest more in portable water provision }\end{array}$ & 67 & 23.3 \\
\hline Public and private partnership in water provision & 114 & 39.6 \\
\hline $\begin{array}{l}\text { Rehabilitation of water supply scheme and } \\
\text { connection and or reconnection of deprived } \\
\text { neighborhoods with the scheme }\end{array}$ & 64 & 22.2 \\
\hline Total & 288 & 100 \\
\hline
\end{tabular}

Source: Authors Field Survey, 2017

\section{Ondo State Water Corporation Official Report}

According to the Department of Engineering, Design and Statistics Ondo State Water Corporation, the corporation was established primarily to provide safe water for the teeming inhabitants of Ondo State. The corporation is an appendage of the state government empowered in financial, human and material resources to carry out her responsibility. Government and her agency provide water to relative inhabitants of Akure and its environs through boreholes and pipe-borne water connected to Ondo Owena Water Scheme and Igbara Oke Water Scheme. Areas not connected with pipe borne water are provided with boreholes. To site boreholes in particular environment or location, the following factors are put into considerations:Water demand or threshold population of not less than 2000 ,geophysical investigation of the terrain to ascertain the suitability or appropriateness of the area in terms of absence of underlying rocks, high volume and quality (colourless, odourless and tasteless) of underground water.

In some cases, the government uses its locus standi to register their preference for a particular location. Should areas identified consider suitable for boreholes after thorough investigations, the borehole is sited 500 meters apart from each other. To complement the water schemes and various boreholes put in place by the state government, the federal government under the leadership of President Olusegun Obasanjo (1999-2007) initiatedOwena Multipurpose Dam designed to supply 60,000 meter cubic of water per day to the inhabitants of Akure and its environs. The sum of 7 billion $(\$ 193,90,582)$ was used by the federal government to put a comprehensive water treatment plant in place.

Thereafter, the project was handed over to the state government under the leadership of Dr. Olusegun Agagu 2003-2009 to finance the water reticulation and distribution networks to the inhabitants of Akure South, Akure North, Idanre, Ifedore, and Ondo West and East. The project was awarded for 14billion $(\$ 387,81,164)$ out of which $\$ 7$ billion $(\$ 193,90,582)$ was paid to the project contractor. Not quite long after the payment, another season 
of the election came; he ran for the second term and was defeated by Dr. Olusegun Mimiko who was on board from 2009 to 2017. Because of the financial implications of the multipurpose dam and manifold political intrigues, the contract formally awarded by the previous administration was revoked and the site abandoned all through his administration. A visit to the treatment plants revealed that a number of capital intensive equipment put in place had won out. One of the achievements of this administration was the creation of a water fountain at Alagbaka axis of Akurethough water supply in this fountain is not meant for domestic uses rather for the beautification of the city landscape. The incumbent Governor barrister Oluwarotimi Akerodolu came on board in 2017 and has not put in place proactive measure to address water supply situations in Akure and its environs. Should this trend continues, any government that will be interested in addressing the situation will end up spending a substantial amount of money to revitalize the treatment plants first before re-awarding the contract of reticulation and distribution networks.

\section{Conclusion and Recommendation}

Nation, state and local districts are governed through the instrumentalities of politics. To assume the position of leadership at local, state and national levels across the globe requires lots of political dynamics. Section 14 subsection $2 \mathrm{~b}$ of the Nigerian Constitution (as amended) stipulates that the welfare and security of the citizens shall be the primary purpose of government. In view of the above, this study examines the role of politics in governance and service delivery (with a particular interest in water provision) in Akure, Nigeria. The contributions of past and present governors of Ondo State from (1999-2017) in water provision were investigated. The study amongst others revealed that water is a vital necessity of life that requires huge financial commitments on the part of the government. Successive governments in Ondo State address the provision of water to the teeming inhabitants of Akure based on their ideology. For example, Governor Adefarati saw water as public goods and relatively maintains the extant water facilities during his reign. Dr. Olusegun Agagu equally saw water as public/social goods and substantially expand the scope of water provision in Akure by constructing boreholes at various strategic locations, investing heavily in maintaining the existing water schemes, reticulation, and distribution networks. Dr. Mimiko saw water as an economic good and reduced budgetary allocation or investment in water provision in Akure and its environs. Most water projects/schemes developed by his predecessor were abandoned such as Owena Multipurpose Dam, Ondo Owena and Igbara Oke Water Schemes. Towards the end of the tenure of Dr. Mimiko, pipe borne water supply in Akure is virtually non-existent. Investment in water provision in the administration of barrister Oluwarotimi Akeredolu experienced massive downward trend. According to the management of Ondo State Water Corporation, 100 million $(\$ 2,770,08.3)$ was budgeted for water provision in the year 2017 but only $\$ 1.2$ million $(\$ 3,324.1)$ was accessed; $\$ 300$ million $(\$ 8,310,25)$ was budgeted in the year 2018 and as of February 2018, the corporation has not been able to access any part of the money.

Based on the above and other findings from the research, the following recommendations were made: Successive government at all levels irrespective of political or party affiliation should make the provision of water free most especially to the poor and the vulnerable group in the society. The provision of water should be seen as a continuum i.e successive government should strive to build on the success of their predecessor regardless of political differences provided the project in question will enhance the quality of life of the citizens. This can be accomplished through legislation by state and National Assembly. World Bank and other International Donors should come to the aid of Ondo State Government by providing grants needed to revamp and distribute water from Ondo Owena and Igbara Oke Water Schemes and Owena Multipurpose Dam to the inhabitants of Akure and its environs. In all, politics should continuously be deployed to institute good governance that will enhance sustainable people-oriented service delivery.

\section{References}

[1]. Afolabi, A. (2008). Improving urban Land Use Planning and Management in Nigeria: The Case of Akure. Theoretical and Empirical Researches in Urban Management 3( 9): 1-14

[2]. Akujuru, C.A., and Enyioko, N.C. (2014). Democracy and Social Service Delivery in Nigeria: A Case Study of Free Medical Programme of Rivers State Government (2007-2013). available at: http://ssrn.com/abstract=2602035

[3]. Arowolo, D.E. and Aluko, O.A. (2012). Democracy, political participation and good governance in Nigeria. International Journal of Development and Sustainability, 1(3): 797-809

[4]. Ayo, B. (2000), "Governance Crisis in Nigeria: Tocqueville's Challenge and Response of African Scholars", inAdedeji, A. \& Ayo, B. (eds). People-Centered Democracy in Nigeria? The Search for alternative systems of Governance at the Grassroots, Ibadan: Heinemann Educational Books (Nigeria) PLC.

[5]. Bamigbetan, A.O. (2016). Pathway to effective public service delivery. Nation Newspaper January 14. 
[6]. Bolatilo, S. and Ibrahim, B.S. (2014). „Challenges of Local Government Administration in Nigeria; an Appraisal of Nigerian Experience. International Journal of Science and Research (IJSR) Vol.3

[7]. Bonnie A, Kehinde B (2007). Public Service and Delivery in Developing Societies: The Nigerian Experience. J. Soc. Sci. 15(2):105-110.

[8]. Brenneman, Adam, \& Kerf, Michel. (2002). Infrastructure \& Poverty Linkages: A Literature Review. Washington, DC: The World Bank Group. (http://www.ilo.org/wcmsp5/groups/public/---ed_emp/---emp_policy/--invest/documents/publication/wcms_asist_8281.pdf)

[9]. Central Bank of Nigeria (2005). Statistical Bulletin. Volume 16, December 2005.

[10]. Chimee, I. N. (2009), "Ideological Flux, Ethnicity, and Corruption: Correlates in Explaining Leadership Failure of Nigeria's Founding Fathers" in Edoh, T. et al (eds.) Opcit.

[11].Diamond, L. (2005), Democracy, Development and Good Governance: The Inseparable Links. A Paper Delivered at the Maiden Annual Democracy and Governance, Ghana, March 1, Lecture of the Ghana Center for Democratic Development (CDD).

[12].Easton, D. (1957). "An Approach to the Analysis of Political Systems", World Politics, 9.

[13]. Ejuvbekpokpo, S. (2012). Cost of Governance on Economic Development in Nigeria. Global Journal of Management and Business Research, 12(13):19-23

[14].Kampung, E.G., and Onenu, E.J. (2013). Budgeting Role, Infrastructural Development and Economic Growth in Nigeria. European Journal of Business and Social Sciences, 2(6):1-15

[15].Famutimi, F. (2012), “Obi, Cleric Decry High Cost of Governance,” The Punch, Saturday, May 26, P. 8.

[16].Gafar, B. B. (2017). The travail of service delivery and developmental failure in post-independence Nigeria. Journal of Public Administration and Policy Research, 9(3), 26-33.

[17].Hernandez, C. (2006). Services Sector: Its Importance for Development and Potential Impacts of its Liberalization. UNDP-Dakar.

[18].Hoogwout, M. (2010). English version Summary of Ph.D. Thesis: The Rationality of Client-Oriented Government.De rationalizes, Niuwegein.

[19].Ichima, S. (2014). Politics and Politicking: The Undoing of Effective Public Administration in Nigeria. Developing Country Studies, 4(19): 51-55. ISSN 2224-607X (Paper) ISSN 2225-0565 (Online)

[20].Igbuzor, O. (2017). An Overview of Service Delivery Initiative: 12 Years After. Paper presented at the national policy dialogue on strategies for improving service delivery in government parastatals, agencies and commissions in Nigeria at State House, Abuja on $27^{\text {th }}$ of March.

[21].Johnson, J. (1991). Aid and Governance in Africa" the Round Table, 320

[22]. Kabuya FI (2011). Development ideas in post-independence: Sub- Saharan Africa. J. Dev. Agr. Econ, 3(1):1-6

[23].Kayode, A; Adagba, S.O. and Anyio, S.F. (2013). Corruption and service delivery: the case of Nigerian public service. Woodpecker Journal of Public Administration, 1(1):1-6

[24].Lasswell, A. (1930). Politics: Who Gets What, When and How, New York: McGraw Hall.

[25].Lawal, O.L (2014) Assessment of Service Provision in Selected Public and Private Residential Neighbourhoods of Akure, Nigeria (Unpublished M.Tech., Thesis submitted to the Department of Urban and Regional Planning, School of Environmental Technology, Federal University of Technology Akure, Ondo State, Nigeria)

[26].Lawal, O.L and Basorun, J.O. (2015). Access to safe Water in Akure: A paradox in Nigerian Urbanized Regions. International Journal of Emerging Knowledge, 3(3): 39-45

[27].Leni, W.; Victoria, C; Maia, k. and Dan, H. (2012). Common Constraints and Incentive Problems in Service Delivery: Overseas Development Institute: London

[28].Majekodunmi, A. (2015). Federalism in Nigeria: The past, current peril and future hopes. Journal of Policy and Development, 9(2):107-120

[29].Municipal Research and Services Centre (1993), Municipal Services Delivery: A Survey of Washington Cities and Towns. Report No 26 (MRSC Centres) Washington.

[30].Natufe, O.I. (2006). Governance and Politics in Nigeria. A lecture delivered at the staff and graduate seminar department of Political Science \& Public AdministrationUniversity of Benin, Benin-City, Edo State, Nigeria on November 21.

[31].Nweke, C.C. (2015) Democracy, Leadership and Nation Building in Nigeria. Ogirisi: a new journal of African Studies, 11: http://dx.doi.org/10.4314/og.v11i 1.8

[32]. Obama, B. (2009). Obama's Speech in Ghana. Accra July 11.https://www.flickr.com/photos/usarmyafrica/3773067890

[33].Odo, L.U. (2015). Democracy and Good Governance in Nigeria: Challenges and Prospects. Global Journal of HumanSocial Science $(F), 15(3): 1-7$

[34].Ogunlana, O.F; Yaqub, J.O and Alhassan, B.O. (2016.) Infrastructure Finance and Development in Nigeria. Arabian Journal of Business and Management Review (Nigerian Chapter), 3(12):44-54

[35].Ojo, E.O. (2012). Constraints on Budgeting and Development Plan Implementation in Nigeria: an Overview. European Journal of Sustainable Development, 1(3):445-456

[36]. Okeke, M.I. and Eme, O.I. (2015). Cost of Governance and its implications on Nigeria's Economy. Kuwait Chapter of Arabian Journal of Business and Management Review, 4(5):44-61 
[37]. Olujimi J \& Olamiju I.O (2011). Regional Analysis of Locations of Public Educational Facilities in Nigeria: The Akure Region Experience. Journal of Geography and Regional Planning 4(7), pp. 428-442, Available online at http://www.academicjournals.org/JGRP

[38].Omotso, F.and Abe, T. (2014). Federalism, Politics, and Governance in Nigeria. Public Policy and Administration Research, 4(7):64-69

[39]. Ondo state government Agro-climatological and Ecological Monitoring Unit (EMU), Akure. on 22nd March 2007.

[40]. Organization for Economic Cooperation and Development (2010), Strategies to Improve Rural Services Delivery.Accessed 01/01/2018

[41]. Otegbulu, A.C. (2013). Governance and management of urban infrastructure services in Lagos Nigeria.Journal of Public Administration and Policy Research, 5(1): 8-21

[42]. Oyedele, S.O (2015). The Nigerian Public Service and Service Delivery under Civil Rule. Journal of Public Administration, Finance and Law, 1:33-43

[43].Pouliquen, L. (2000). Poverty and Infrastructure. World Development Report 2001 Background Paper, No. 27911. Washington, DC: The World Bank Group.

[44].Rodrik D (2008). Thinking about Governance, the World Bank Publication. April, Washington DC, USA.

[45].Uhunmwuangho, S. O. and Ekpu, C. (2012). Analysis of Socio-Political Implication of Infrastructural Decay in Nigeria. An International Multidisciplinary Journal, Ethiopia, 6 (4):40-58

[46]. World Bank (2004). World Development Report 2004: Making Services Work for Poor People. Washington, DC: World Bank

[47].World Bank. (2010). Innovative Finance for Development Solutions: Initiatives of the World Bank Group. Washington, DC: The World Bank Group.

[48].Zhang, Jing. (2012). The Impact of Water Quality on Health: Evidence from the Drinking Water Infrastructure Program in Rural China. Journal of Health Economics, 31(1): 122-134. 